のノックのほうが問題であり, わが国の状況に㐫つた ガソリンの最適組成を求める必要がある。乞のために は試験法とのものにも問題があり, わが国の道路条件 に適した走行オクタン価試験法を発展させることも必 要のよ5に思われる。関連技術者の協力はますます重 要である。

今回受賞の栄に浴した「内燃機燃料および調滑油の 実用性能に関する研究」は，昭和25年太平洋岸製油所 が再開されるに伴い，日本石油株式会社中央技術研究 所の正常の業務が再開されると同時に, 熊谷研究室に おいて同研究室長の指導のもとに始められたものであ る。
この研究の重要性を認められて，その実施を命ぜら れた日本石油株式会社故佐々木前社長, 栗田現社長を 始めとする重役首脳諸公, 特に直接の最高責任者とし てこの研究を強力に推進された日石化学林常務, 日石 牧製油部長, 熊谷中央技術研究所長和よび研究実施の 担当者である南晃, 中島清, 内沼一雄乞の他多数の諸 君ならびに前中央技術研究所長多田知十郎氏に対し厚 く御礼申上げる。 当然料協会はわれわれのこの研究開始の当初からそ の重要性を認識され, 直接, 間接に御指導御援助を戴 いた。役員諸公および会員諸见に厚く御礼申上げると ともに，さらに今後の御指導を御願いする。

\title{
Some Problems for the Performance of Engine Oils and Gasolines
}

\author{
by Yutaka Katayama
}

(Nippon Oil Co.)

SYNOPSIS :- The author describes the significance of the laboratory oxidation tests for lubricants and the bench tests with Japnese full scale engines of "Nissan", "Isuzu", "Dutsan". and others with compared to Lauson and Caterpillor engine tests. He also reviews the development of motor engines and required octane number in Japan, and the relation between laboratory and road octane number. Then he points out some problems for evaluation on the performance of lubricants in motor cars and for motor gasoline octane number.

\section{正誤 改 訂}

第38巻，382 号田中氏論文中，下記のごとく正誤改訂致します。

鿁

P. 65 右側 7 行目

P. 66 第 2 図標題

"

P. 68 第 6 表中の設備能力改訂

$\begin{array}{ll}\text { カーダンバー } & 500 \mathrm{t} / \mathrm{h} \\ \text { 貯炭場 } & 100,000 \mathrm{t} \\ \text { スタツカー } & 500 \mathrm{t} / \mathrm{h} \\ \text { ジブローダー } & 500 \mathrm{t} / \mathrm{h} \\ \text { ベルトュンベャー } & 500 \mathrm{t} / \mathrm{h} \\ \text { 粉砕機 } & 250 \mathrm{t} / \mathrm{h} \\ \text { 混炭機 } & 500 \mathrm{t} / \mathrm{h}\end{array}$

正 鉄 鋼製産 鉄 鋼 生産 Lay out tne Lay out of the Camara Works

$350 \mathrm{t} / \mathrm{h}$

$105,000 \mathrm{t}$

$350 \mathrm{t} / \mathrm{h}$

$350 \mathrm{t} / \mathrm{h}$

$350 \mathrm{t} / \mathrm{h}$

$200 \mathrm{t} / \mathrm{h}$

$400 \mathrm{t} / \mathrm{h}$ 